Biochim Biophys Acta. 2011 November ; 1810(11): 1091-1095. doi:10.1016/j.bbagen.2011.04.016.

\title{
Isoprostanes and Asthma
}

\author{
Judith A. Voynow* and Apparao Kummarapurugu \\ Division of Pediatric Pulmonary and Sleep Medicine, Box 102360, Duke University Medical \\ Center, Durham, NC 27710, USA
}

\begin{abstract}
Isoprostanes are prostaglandin (PG)-like compounds generated in vivo following oxidative stress by non-enzymatic peroxidation of polyunsaturated fatty acids, including arachidonic acid. They are named based on their prostane ring structure and by the localization of hydroxyl groups on the carbon side chain; these structural differences result in a broad array of isoprostane molecules with varying biological properties. Generation of specific isoprostanes is also regulated by host cell redox conditions; reducing conditions favor $\mathrm{F}_{2}$-isoprostane production while under conditions with deficient antioxidant capacity, $\mathrm{D}_{2}$ - and $\mathrm{E}_{2}$-isoprostanes are formed. $\mathrm{F}_{2}$-isoprostanes $\left(\mathrm{F}_{2}\right.$-isoP) are considered reliable markers of oxidative stress in pulmonary diseases including asthma. Importantly, $\mathrm{F}_{2}$-isoP and other isoprostanes function as ligands for PG receptors, and potentially other receptors that have not yet been identified. They have been reported to have important biological properties in many organs. In the lung, isoprostanes regulate cellular processes affecting airway smooth muscle tone, neural secretion, epithelial ion flux, endothelial cell adhesion and permeability, and macrophage adhesion and function. In this review, we will summarize the evidence that $\mathrm{F}_{2}$-isoP functions as a marker of oxidative stress in asthma, and that $\mathrm{F}_{2}$-isoP and other isoprostanes exert biological effects that contribute to the pathogenesis of asthma.
\end{abstract}

\section{Keywords}

isoprostane; cyclopentenone; oxidative stress; asthma; airway smooth muscle

\section{Introduction}

Isoprostanes are PG-like compounds derived from free radical peroxidation of polyunsaturated fatty acids (primarily arachidonic acid) in tissues. They are isomers of enzymatically-derived PGs, but in contrast to PGs, cyclooxygenases (COX-1 and COX-2) are not required for isoprostane formation. Such peroxidation reactions lead to the formation of many different structures named for the prostane ring structure they most closely resemble, and regioisomers are named for the location of a hydroxyl group on the alkyl chain [1]. One class of isoprostanes in particular, the $\mathrm{F}_{2}$-isoprostanes $\left(\mathrm{F}_{2}\right.$-isoP) are stable molecules that are formed in vivo under conditions of oxidative stress. $\mathrm{F}_{2}$-isoPs are considered reliable markers of oxidative stress in disease, but in addition, they have important biological properties in many tissues [2] including the lung [3]. In this review, we

\footnotetext{
(C) 2011 Elsevier B.V. All rights reserved.

*Corresponding Author, Division of Pediatric Pulmonary and Sleep Medicine, Box 102360, Duke University Medical Center, Durham, NC 27710, USA Phone Number: 919-684-3364; FAX: 919-684-2292.

Publisher's Disclaimer: This is a PDF file of an unedited manuscript that has been accepted for publication. As a service to our customers we are providing this early version of the manuscript. The manuscript will undergo copyediting, typesetting, and review of the resulting proof before it is published in its final citable form. Please note that during the production process errors may be discovered which could affect the content, and all legal disclaimers that apply to the journal pertain.
} 
will summarize the evidence that $\mathrm{F}_{2}$-isoP functions as a marker of oxidative stress in asthma, and that $\mathrm{F}_{2}$-isoP and potentially other isoprostanes exert biological effects that contribute to the pathogenesis of asthma.

\section{Isoprostane Biochemistry}

The first class of isoprostanes discovered was the $\mathrm{F}_{2}$-isoprostanes $\left(\mathrm{F}_{2}\right.$-isoP) named because they have the same F-type prostane ring as $\mathrm{PGF}_{2 \alpha}$. Since this discovery, several other classes of isoprostanes were discovered and named for the $\mathrm{PG}$ with a common prostane ring structure including $\mathrm{D}_{2}$-isoP, $\mathrm{E}_{2}$-isoP, $\mathrm{J}_{2}$-isoP, and $\mathrm{A}_{2}$-isoP [1]. There are a few key distinctions between isoprostanes and PGs. Isoprostane side-chains are mainly cis to the cyclopentane ring, while PG side chains are trans isomers [1, 4]. Isoprostanes are formed from polyunsaturated fatty acids including arachidonic acid in situ in lipid membranes and the isoprostanes are then released by phospholipases. In contrast, PGs are formed from free arachidonic acid. Recently, it has been reported that isoprostanes may be formed from docosahexaenoic acid or eicosapentaenoic acid in addition to arachidonic acid [5-7].

Isoprostane structure is dictated not only by the substrate polyunsaturated acid but also by cellular conditions during the peroxidation process. The net formation of $\mathrm{F}_{2}$-isoP versus $\mathrm{D}_{2}$ isoP and $\mathrm{E}_{2}$-isoP is controlled by the reduction-oxidation status of the cell, the presence or absence of glutathione, and by the presence of oxidative stress [8]. Under reducing conditions, $\mathrm{F}_{2}$-isoP is favored, while under oxidizing conditions, isoprostane formation is shifted to produce $\mathrm{D}_{2}$ - and $\mathrm{E}_{2}$-isoP. We have recently reported that host genetic factors also regulate $\mathrm{F}_{2}$-isoP generation in response to ozone. The loss of NADPH quinone oxidoreductase 1 (NQO1), an enzyme that reduces cellular hydroquinones, results in decreased $\mathrm{F}_{2}$-isoP formation following ozone exposure [9]. Importantly, a shift in isoprostane production from $\mathrm{F}_{2}$-isoP to $\mathrm{D}_{2}$ - and $\mathrm{E}_{2}$-isoP may have profound effects on cellular functions. $\mathrm{D}_{2}$ - and $\mathrm{E}_{2}$-isoP are highly reactive and undergo dehydration to form cyclopentenones, $\mathrm{J}_{2}$-isoP and $\mathrm{A}_{2}$-isoP respectively [4] (Figure 1). The cyclopentenone ring is highly reactive and forms Michael adducts with Cys residues in proteins or glutathione; these modifications may affect enzyme activities resulting in several different biological effects including augmenting antioxidant capacity [10] and inhibiting inflammatory cascades $[10,11]$.

The production and metabolism of isoprostanes have been reported in most detail for $15-\mathrm{F}_{2 t^{-}}$ isoP. Arachidonic acid is exposed to oxygen radicals resulting in the abstraction of a bisallylic hydrogen atom, and formation of a lipid peroxide radical and endocyclization. An additional oxygen molecule is added to form an unstable bicyclic endoperoxide intermediate. After reduction, four potential $\mathrm{F}_{2}$-isoP families are formed, which are designated as 5-, 8-, 12-, or 15-series regioisomers based on the location of the side chain hydroxyl residue [12] (Figure 1). Each regioisomers has 16 stereoisomers yielding a large variety of structures. The esterified isoprostanes are released as free molecules by phospholipase $\mathrm{A}_{2}$ or platelet activating factor acetylhydrolase activity, and are rapidly released into the circulation, and excreted into the urine. $\mathrm{F}_{2}$-isoP is metabolized by an enzymatic process similar to the $\mathrm{PG}$ degradation pathway. Beta-oxidation and reduction result in $\mathrm{F}_{2}$-isoP degradation products including 2,3-dinor-8-isoPF ${ }_{2 \alpha}$ and 2,3-dinor-5,6dihydro-8-PG $\mathrm{F}_{2 \alpha}$; these degradation products and the parent molecule $\mathrm{F}_{2}$-isoP can be detected and quantified in urine $[12,13]$. Of all of the $\mathrm{F}_{2}$-isoP regioisomers, $15-\mathrm{F}_{2 \mathrm{t}}$-isoP (also known as 8 -iso- $\mathrm{PGF}_{2 \alpha}$ or 8 -epi- $\mathrm{PGF}_{2 \alpha}$ ) has received most attention due to its utility as a biomarker of oxidative stress $[12,14]$.

15- $\mathrm{F}_{2 \mathrm{t}}$-isoP can be quantified by EIA, RIA, and by GC-MS or by LC or UPLC followed by tandem MS $[12,15]$. Urinary $15-\mathrm{F}_{2 \mathrm{t}}-\mathrm{isoP}$ and its oxidation/ reduction metabolites require 
GC-MS or LC-tandem MS for quantitation of all three isoP species. Immunoassays are validated to exclude other isoprostanes or PGs but are less specific and sensitive than MS [12]. GC-MS or LC-MS permits high throughput analysis with little derivatization of samples but is more expensive and requires skilled technicians [12]. Interpretation of $\mathrm{F}_{2^{-}}$ isoP as a biomarker of oxidative stress requires consideration of the disease process to determine whether the timing of sample collection, and the source of the biological sample will provide an accurate reflection of oxidative stress [16].

\section{5- $F_{2 t}$-isoP, a Biomarker of Oxidative Stress}

$15-\mathrm{F}_{2 \mathrm{t}}$-isoP is increased following exposure to environmental pollutants or during exacerbations of inflammatory diseases, and can be quantified in many tissues and body fluids including urine, bronchoalveolar lavage, exhaled breath condensate (EBC), and plasma. Ozone and tobacco smoke increase lung oxidative stress as detected by $15-\mathrm{F}_{2 \mathrm{t}}$-isoP even in healthy individuals. In healthy young adults, acute laboratory exposures of ozone $(0.40 \mathrm{ppm}, 2 \mathrm{~h})$ immediately decreased airflow $\left(\mathrm{FEV}_{1}\right)$, and at $4 \mathrm{~h}$ post-exposure, increased EBC levels of $15-\mathrm{F}_{2 \mathrm{t}}$-isoP [17]. Similar results were obtained by Alfaro and colleagues [18], except that they demonstrated that in addition to the healthy subjects susceptible to ozone, there is another group of healthy subjects who are not sensitive to ozone and thus are resistant to developing airway obstruction or elevated $15-\mathrm{F}_{2 \mathrm{t}}$-isoP in EBC. Importantly, in healthy individuals, cumulative ozone exposure (average $0.043 \mathrm{ppm}$ per month) in association with increased particulate matter with an aerodynamic diameter of $\leq 10$ microns $\left(\mathrm{PM}_{10}\right)$ and nitrogen dioxide, is associated with increased plasma $\mathrm{F}_{2}$-isoP [19]. In healthy individuals, tobacco smoking increases sputum $\mathrm{F}_{2}$-isoP [20], plasma $\mathrm{F}_{2}$-isoP, and urinary metabolites of $\mathrm{F}_{2}$-isoP [21]. Cumulative exposure of non-smokers to second-hand tobacco smoke exposure (30 cigarettes smoked/ $\mathrm{h} ; 1 \mathrm{~h}$ exposure per day for 12 days) results in increased plasma $\mathrm{F}_{2}$-isoP [22].

$15-\mathrm{F}_{2 \mathrm{t}}$-isoP levels are significantly increased in diverse human disease conditions which share increased oxidative stress as a common pathologic feature including cardiovascular diseases, chronic liver disease, chronic renal disease, neurodegenerative diseases, type 2 diabetes mellitus, obesity, and inflammatory diseases such as arthritis [12]. Elevated $15-\mathrm{F}_{2 \mathrm{t}^{-}}$ isoP has also been a consistent biomarker of inflammatory pulmonary diseases including ARDS, CF, pulmonary hypertension, chronic obstructive pulmonary disease, interstitial lung disease, and asthma [12].

\section{Asthma and Oxidative Stress}

Asthma is one of the most common chronic pulmonary diseases, affecting approximately $10 \%$ of the population. It is characterized by reversible airflow obstruction, airway remodeling, and inflammation which is biased toward Th2 cytokine production and involves mast cells, eosinophils, lymphocytes, macrophages and neutrophils [23]. An important pathogenic feature of the disease is the imbalance of oxidative stress and antioxidant capacity resulting in the generation of reactive oxygen species and reactive nitrogen species that are both biomarkers of disease activity and effectors of disease progression [24].

$15-\mathrm{F}_{2 \mathrm{t}}$-isoP has been consistently elevated in exhaled breath condensate, plasma and urine in asthma compared to healthy controls (Table 1). Importantly, these results have been confirmed by other biomarkers of oxidative stress in respiratory secretions, plasma and urine including nitrotyrosine, 3-bromotyrosine [25], NO [24], and GSH: GSSG ratio [26] and leukotrienes (Table 1). 15- $\mathrm{F}_{2 \mathrm{t}}$-isoP has been reported to be increased in children with asthma and not affected by inhaled corticosteroid (ICS) therapy [27, 28]. 15- $\mathrm{F}_{2 \mathrm{t}}$-isoP is increased following allergen challenge [29], following bacterial bronchitis [30], following eosinophilic inflammation [31], and in exercise-induced bronchospasm [32]. 15- $\mathrm{F}_{2 \mathrm{t}}$-isoP varies by 
asthma severity [25]; it increases during exacerbations of asthma [27] and decreases when allergen triggers such as house dust mite (HDM) are avoided [33]. Overall, elevated levels of $15-\mathrm{F}_{2 \mathrm{t}}$-isoP in asthma may reflect acute exposures to oxidants that trigger asthma such as pollutants or tobacco smoke. Alternatively, elevated levels of $15-\mathrm{F}_{2 \mathrm{t}}$-isoP may directly reflect the inflammation associated with exacerbations of asthma due to infections or allergens. Increased levels of $15-\mathrm{F}_{2 \mathrm{t}}$-isoP or the urinary metabolite, 2,3-dinor-8-epiPGF $2 \alpha$ are stable markers that reflect oxidative stress. Although there is no evidence that changes in isoprostane levels precede immediate airflow obstruction, the sustained increase in isoprostanes may regulate longer-term airway remodeling or airway smooth muscle function.

\section{Asthma and the Biological Impact of Isoprostanes}

Asthma is defined as recurrent exacerbations of reversible airflow obstruction related to bronchospasm in response to allergen exposures, infections, or pollutant exposures. Over time, asthmatic airways undergo remodeling that contributes to impaired physiology; these airway changes are characterized by mucous cell metaplasia and regions of epithelial loss; subepithelial influx of myofibroblasts and collagen deposition resulting in basement membrane thickening; and angiogenesis. During exacerbations of asthma, inflammatory cells in the airway, including eosinophils, $\mathrm{Th}_{2}$ lymphocytes, neutrophils, macrophages and mast cells, are activated and release mediators that interact with structural cells to trigger airway hyperresponsiveness and remodeling [34]. Interactions between environmental triggers, inflammatory cells and structural cells result in the generation of reactive oxygen species including the generation of isoprostanes. Recent reports suggest that isoprostanes have biologic functions that contribute to pathophysiologic changes in asthma.

\section{Isoprostanes and Airway Smooth Muscle Signaling}

Given the structural similarity of isoprostanes to prostanoids, it is predicted that isoprostanes can influence ASM function through activation of prostanoid receptors. $15-\mathrm{F}_{2 \mathrm{t}}$-isoP activates thromboxane receptor (TP) $[35,36]$ and possibly a distinct yet uncharacterized specific receptor [37], while $15-\mathrm{E}_{2 \mathrm{t}}$-isoP activates $\mathrm{TP}$, PGF receptor (FP), and $\mathrm{PGE}_{1-4}$ receptors $\left(\mathrm{EP}_{1-4}\right)$ [38]. $\mathrm{EP}_{1-4}$ receptors compete for ligand binding and stimulate distinct signaling pathways, resulting in a broad range of physiologic effects from bronchoconstriction to bronchial smooth muscle relaxation depending on the concentration of the activating ligand [39].

Isoprostanes regulate human airway smooth muscle (ASM) tone and hyperresponsiveness to stimuli $[38,40]$. Both 8-iso- $\mathrm{PGE}_{2}$ and 8 -iso- $\mathrm{PGF}_{2 \alpha}$ induce airway smooth muscle contractions; although 8-iso- $\mathrm{PGE}_{2}$ is reported to be 10-100 fold more potent than 8-iso$\mathrm{PGF}_{2 \alpha}$. In human and guinea pig airways, ASM contraction to 8-iso-PGF ${ }_{1 \alpha}(5.9 \mu \mathrm{M}) 8$-iso$\mathrm{PGF}_{2 \alpha}(6.2 \mu \mathrm{M})$, and 8-iso-PGE $2(7.0 \mu \mathrm{M})$ is mediated through TP but not through EP receptors [41, 42]. TP receptor activation is functionally coupled to calcium influx [35, 36] and signaling through monomeric G-protein RhoA and its downstream effector RhoAassociated kinase $[36,42,43]$. However, a different isoprostane, 8 -iso- $\mathrm{PGF}_{3 \alpha}\left(\log \mathrm{IC}_{50}=4.9\right)$ relaxes human ASM, suggesting that this isoP activates a non-TP receptor [42]. In canine and porcine ASM, activation of specific EP receptors results in bronchodilation [44]. In canine and porcine trachea, E-ring isoprostanes, 8-iso- $\mathrm{PGE}_{1}$ and 8-iso- $\mathrm{PGE}_{2}$ with $\log \mathrm{IC}_{50}$ values of 6.9 and 6.9 respectively, activate EP receptors, and relax ASM following precontraction with carbachol [45]. Thus the isoprostane species and the receptor subtypes expressed determine the airway smooth muscle physiologic response.

There are species differences in the action of isoPs to regulate ASM contraction that are regulated by differences in receptor expression. Bovine ASM contracts in response to 8-iso- 
$\mathrm{PGE}_{2}$, but these responses are mediated through a non-TP, non-EP receptor [46]. In canine airways, neither 8-iso- $\mathrm{PGE}_{2}$ nor 8 -iso- $\mathrm{PGF}_{2 \alpha}$ isoprostanes have an excitatory effect. Neither dog nor porcine airways express TP receptors, therefore none of the isoprostanes evoke constrictor responses in these species [42] [45].

Isoprostanes also regulate ASM tone by regulating prejunctional neuronal acetylcholine secretion. 8-iso-PGF ${ }_{2 \alpha}$ acts at the prejunctional neuron to inhibit electrical field stimulated (EFS)- acetylcholine release in guinea pig trachea [47]. E-ring isoprostanes also inhibit EFSacetylcholine release from prejunctional neurons in guinea pig trachea; this neural effect is inihibited by an $\mathrm{EP}_{3}$-receptor specific inhibitor [48]. In contrast, in bovine trachea, 15- $\mathrm{E}_{2 \mathrm{t}^{-}}$ isoP augments EFS-acetylcholine release via FP receptors [49]. The effect of isoprotanes on neutrally-mediated ASM contraction has not yet been evaluated in human airway.

Finally, isoprostanes also regulate chemokine production in ASM cells that contribute to the inflammatory cascade. 8-iso-PGE1 and - $\mathrm{E}_{2}$ augment IL-1 $\beta$-induced G-CSF in human ASM via cAMP signaling and specific $\mathrm{EP}_{2}$ and $\mathrm{EP}_{4}$ receptor activation [50]. This report adds to the growing body of evidence that ASM secrete inflammatory cytokines and contribute to the inflammatory milieu in the airway [51].

\section{Isoprostanes and Inflammatory cells}

Macrophages are sentinel immune cells in the lower respiratory tract detecting environmental stress. They play a major role in regulating the innate immune response to environmental pollutants by secreting cytokines to enhance neutrophil chemotaxis [52]. Exposure of human alveolar macrophages to elemental carbon in ultrafine particles induces 8 -iso-PGF $2 \alpha$ production [53]. Isoprostane (8-iso- $\mathrm{PGF}_{2 \alpha}$ ) stimulates human macrophage binding to human venous endothelial cells [54] and increases macrophage IL-8 expression by activating Erk1/2 and p38 MAP kinase signaling [55]. Isoprostanes (8-iso-PGF ${ }_{2 \alpha}$ and 8iso- $\mathrm{PGE}_{2}$ ) may further contribute to neutrophilic inflammation by increasing neutrophil adhesion to human venous endothelial cells [56], and by increasing endothelial cell permeability in response to oxidative stress [57].

In contrast to the effects of 8 -iso- $\mathrm{PGF}_{2 \alpha}$ to enhance neutrophilic inflammation in the airway, cyclopentenone isoprostanes blunt NF- $\mathrm{kB}$ activated inflammatory cascades. Exposure of macrophages to $15-\mathrm{A}_{2 \mathrm{t}}$-isoP inhibits lipopolysaccharide-stimulated NF- $\mathrm{KB}$ transcriptional

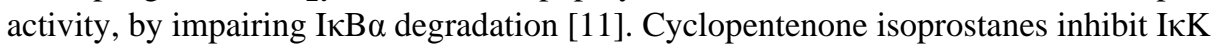
enzyme activity by forming a direct adduct to a susceptible Cys residue [58].

Cyclopentenone isoprostanes may attack susceptible Cys residues on any molecule affecting protein or enzyme function. For example, cyclopentenone isoprostanes modify a Cys domain in Keap1, a protein that sequesters the transcription factor, NF-E2 related factor-2 (Nrf2) in the cytoplasm. Oxidation of Keap1, results in release of Nrf2, translocalization to the nucleus and activation of antioxidant response element (ARE) domains in promoters of Phase II response genes which enhance antioxidant enzyme activities [10]. Together, the mechanisms of cyclopentenone isoprostanes formed under cellular oxidant conditions may stimulate macrophages to respond paradoxically to air pollutants by enhancing antioxidant capacity and inhibiting inflammation [59].

\section{Isoprostanes and Epithelial cells}

There are a few reports that isoprostanes regulate anion conductance across epithelial cells. The E-ring isoprostane, 8-iso $\mathrm{PGE}_{2}$, regulates anion efflux in Calu-3, an epithelial cancer cell line, in part though the activation of the TP receptor [60] and also in part by the activation of the $\mathrm{EP}_{4}$ prostanoid receptor via PKA and PI3 kinase activation [61]. This conductance is regulated by CFTR [61]. 8-iso $\mathrm{PGE}_{2}$ regulates chloride transepithelial 
conductance in primary bovine tracheal epithelial cells [62] via the $\mathrm{EP}_{4}$ receptor coupled to adenylate cyclase and soluble guanylate cyclase. In contrast, F-ring isomers do not regulate changes in epithelial short circuit current [62]. Ionic currents at the apical plasma membrane affect airway surface fluid balance and mucus hydration and clearance; all of these factors are important components of the pathophysiology of asthma and CF. Given the potential differences in isoprostane generation and PG receptor expression between these model systems and primary human airway epithelial cells, the function of isoprostanes in primary human airway epithelial cells still needs to be evaluated.

\section{Summary}

Isoprostanes are upregulated in asthma under conditions that cause asthma exacerbations such as allergen exposure, infections and air pollutant exposures. It is well established that 8 -isoPGF $2 \alpha$ is a stable biomarker of oxidative stress that can be detected in BAL, sputum, $\mathrm{EBC}$, blood and urine, and is upregulated in asthma exacerbations following exposures to triggers. However, 8 -isoPGF $2 \alpha$ is not only a biomarker; this and other isoprostanes have biological functions that have been reported in most airway cells and that potentially contribute to the pathophysiology of asthma. The generation of specific isoprostanes varies depending on the native redox status of the cell and the quantity and duration of environmental oxidative stress. Importantly, different isoprostanes may have opposite functions within a tissue and these functions also vary by the isoprostane receptors present in the tissue. Therefore further investigation is warranted to determine the function of isoprostanes in primary human airway tissues under normal homeostatic conditions and under the stress of triggers that exacerbate asthma.

\section{Research Highlights}

- Isoprostanes are non-enzymatic peroxidation products of polyunsaturated fatty acids.

- F2-isoprostane, a stable biomarker of oxidative stress, is increased in asthma.

- Isoprostanes activate receptors to regulate airway and immune functions in asthma.

\section{Abbreviations}

$\begin{array}{ll}\text { ARE } & \text { antioxidant response element } \\ \text { ASM } & \text { airway smooth muscle } \\ \text { COX } & \text { Cyclooxygenase } \\ \text { EFS } & \text { electrical field stimulation } \\ \text { F } \text {-isoP } & \text { F }_{2} \text {-isoprostanes } \\ \text { GC } & \text { Gas chromatography } \\ \text { HDM } & \text { House dust mite } \\ \text { ICS } & \text { inhaled corticosteroids } \\ \text { LC } & \text { liquid chromatography } \\ \text { MS } & \text { mass spectrometry } \\ \text { Nrf2 } & \text { NF-E2 related factor-2 }\end{array}$


$\begin{array}{ll}\text { PG } & \text { prostaglandin } \\ \text { RIA } & \text { radioimmunoassay } \\ \text { EIA } & \text { enzyme-linked immunoassay } \\ \text { UPLC } & \text { ultraperformance liquid chromatography }\end{array}$

\section{Acknowledgments}

This manuscript is supported by HL082504 and ES016836 (JAV)

\section{References}

1. Milne GL, Yin H, Morrow JD. Human biochemistry of the isoprostane pathway. The Journal of biological chemistry. 2008; 283:15533-15537. [PubMed: 18285331]

2. Cracowski JL, Durand T, Bessard G. Isoprostanes as a biomarker of lipid peroxidation in humans: physiology, pharmacology and clinical implications. Trends Pharmacol Sci. 2002; 23:360-366. [PubMed: 12377577]

3. Janssen LJ, Catalli A, Helli P. The pulmonary biology of isoprostanes. Antioxidants \& redox signaling. 2005; 7:244-255. [PubMed: 15650412]

4. Musiek ES, Yin H, Milne GL, Morrow JD. Recent advances in the biochemistry and clinical relevance of the isoprostane pathway. Lipids. 2005; 40:987-994. [PubMed: 16382569]

5. Musiek ES, Brooks JD, Joo M, Brunoldi E, Porta A, Zanoni G, Vidari G, Blackwell TS, Montine TJ, Milne GL, McLaughlin B, Morrow JD. Electrophilic cyclopentenone neuroprostanes are antiinflammatory mediators formed from the peroxidation of the omega-3 polyunsaturated fatty acid docosahexaenoic acid. The Journal of biological chemistry. 2008; 283:19927-19935. [PubMed: 18490445]

6. Gao L, Wang J, Sekhar KR, Yin H, Yared NF, Schneider SN, Sasi S, Dalton TP, Anderson ME, Chan JY, Morrow JD, Freeman ML. Novel n-3 fatty acid oxidation products activate Nrf2 by destabilizing the association between Keap1 and Cullin3. The Journal of biological chemistry. 2007; 282:2529-2537. [PubMed: 17127771]

7. Song WL, Paschos G, Fries S, Reilly MP, Yu Y, Rokach J, Chang CT, Patel P, Lawson JA, Fitzgerald GA. Novel eicosapentaenoic acid-derived F3-isoprostanes as biomarkers of lipid peroxidation. The Journal of biological chemistry. 2009; 284:23636-23643. [PubMed: 19520854]

8. Morrow JD, Roberts LJ, Daniel VC, Awad JA, Mirochnitchenko O, Swift LL, Burk RF. Comparison of formation of D2/E2-isoprostanes and F2-isoprostanes in vitro and in vivo--effects of oxygen tension and glutathione. Archives of biochemistry and biophysics. 1998; 353:160-171. [PubMed: 9578611]

9. Voynow JA, Fischer BM, Zheng S, Potts E, Grover A, Jaiswal AK, Ghio AJ, Foster WM. NAD(P)H Quinone Oxidoreductase 1 Is Essential for Ozone-induced Oxidative Stress in Mice and Humans. Am J Respir Cell Mol Biol. 2009; 41:107-113. [PubMed: 19059883]

10. Levonen AL, Landar A, Ramachandran A, Ceaser EK, Dickinson DA, Zanoni G, Morrow JD, Darley-Usmar VM. Cellular mechanisms of redox cell signalling: role of cysteine modification in controlling antioxidant defences in response to electrophilic lipid oxidation products. The Biochemical journal. 2004; 378:373-382. [PubMed: 14616092]

11. Musiek ES, Gao L, Milne GL, Han W, Everhart MB, Wang D, Backlund MG, DuBois RN, Zanoni G, Vidari G, Blackwell TS, Morrow JD. Cyclopentenone isoprostanes inhibit the inflammatory response in macrophages. The Journal of biological chemistry. 2005; 280:35562-35570. [PubMed: 16100121]

12. Basu S. F2-isoprostanes in human health and diseases: from molecular mechanisms to clinical implications. Antioxidants \& redox signaling. 2008; 10:1405-1434. [PubMed: 18522490]

13. Roberts LJ 2nd, Moore KP, Zackert WE, Oates JA, Morrow JD. Identification of the major urinary metabolite of the F2-isoprostane 8-iso-prostaglandin F2alpha in humans. The Journal of biological chemistry. 1996; 271:20617-20620. [PubMed: 8702808] 
14. Morrow JD, Roberts LJ. The isoprostanes: their role as an index of oxidant stress status in human pulmonary disease. American journal of respiratory and critical care medicine. 2002; 166:S25S30. [PubMed: 12471085]

15. Zhang H, Il'yasova D, Sztaray J, Young SP, Wang F, Millington DS. Quantification of the oxidative damage biomarker 2,3-dinor-8-isoprostaglandin-F(2alpha) in human urine using liquid chromatography-tandem mass spectrometry. Analytical biochemistry. 2010; 399:302-304. [PubMed: 20026293]

16. Halliwell B, Lee CY. Using isoprostanes as biomarkers of oxidative stress: some rarely considered issues. Antioxidants \& redox signaling. 2010; 13:145-156. [PubMed: 20001743]

17. Montuschi P, Nightingale JA, Kharitonov SA, Barnes PJ. Ozone-induced increase in exhaled 8isoprostane in healthy subjects is resistant to inhaled budesonide. Free radical biology \& medicine. 2002; 33:1403-1408. [PubMed: 12419472]

18. Alfaro MF, Walby WF, Adams WC, Schelegle ES. Breath condensate levels of 8-isoprostane and leukotriene B4 after ozone inhalation are greater in sensitive versus nonsensitive subjects. Experimental lung research. 2007; 33:115-133. [PubMed: 17558675]

19. Chen C, Arjomandi M, Balmes J, Tager I, Holland N. Effects of chronic and acute ozone exposure on lipid peroxidation and antioxidant capacity in healthy young adults. Environmental health perspectives. 2007; 115:1732-1737. [PubMed: 18087591]

20. Kinnula VL, Ilumets H, Myllarniemi M, Sovijarvi A, Rytila P. 8-Isoprostane as a marker of oxidative stress in nonsymptomatic cigarette smokers and COPD. Eur Respir J. 2007; 29:51-55. [PubMed: 17050565]

21. Morrow JD, Frei B, Longmire AW, Gaziano JM, Lynch SM, Shyr Y, Strauss WE, Oates JA, Roberts LJ 2nd. Increase in circulating products of lipid peroxidation (F2-isoprostanes) in smokers. Smoking as a cause of oxidative damage. The New England journal of medicine. 1995; 332:1198-1203. [PubMed: 7700313]

22. Ahmadzadehfar H, Oguogho A, Efthimiou Y, Kritz H, Sinzinger H. Passive cigarette smoking increases isoprostane formation. Life Sci. 2006; 78:894-897. [PubMed: 16165164]

23. Murphy DM, O'Byrne PM. Recent advances in the pathophysiology of asthma. Chest. 2010; 137:1417-1426. [PubMed: 20525652]

24. Comhair SA, Erzurum SC. Redox control of asthma: molecular mechanisms and therapeutic opportunities. Antioxidants \& redox signaling. 2010; 12:93-124. [PubMed: 19634987]

25. Wedes SH, Khatri SB, Zhang R, Wu W, Comhair SA, Wenzel S, Teague WG, Israel E, Erzurum SC, Hazen SL. Noninvasive markers of airway inflammation in asthma. Clin Transl Sci. 2009; 2:112-117. [PubMed: 20234847]

26. Fitzpatrick AM, Teague WG, Holguin F, Yeh M, Brown LA. Airway glutathione homeostasis is altered in children with severe asthma: evidence for oxidant stress. The Journal of allergy and clinical immunology. 2009; 123:146-152. e148. [PubMed: 19130935]

27. Baraldi E, Carraro S, Alinovi R, Pesci A, Ghiro L, Bodini A, Piacentini G, Zacchello F, Zanconato S. Cysteinyl leukotrienes and 8-isoprostane in exhaled breath condensate of children with asthma exacerbations. Thorax. 2003; 58:505-509. [PubMed: 12775861]

28. Shahid SK, Kharitonov SA, Wilson NM, Bush A, Barnes PJ. Exhaled 8-isoprostane in childhood asthma. Respir Res. 2005; 6:79. [PubMed: 16042771]

29. Dworski R, Murray JJ, Roberts LJ 2nd, Oates JA, Morrow JD, Fisher L, Sheller JR. Allergeninduced synthesis of $F(2)$-isoprostanes in atopic asthmatics. Evidence for oxidant stress. American journal of respiratory and critical care medicine. 1999; 160:1947-1951. [PubMed: 10588611]

30. Wood LG, Simpson JL, Hansbro PM, Gibson PG. Potentially pathogenic bacteria cultured from the sputum of stable asthmatics are associated with increased 8-isoprostane and airway neutrophilia. Free radical research. 2010; 44:146-154. [PubMed: 19922242]

31. Aggarwal S, Moodley YP, Thompson PJ, Misso NL. Prostaglandin E2 and cysteinyl leukotriene concentrations in sputum: association with asthma severity and eosinophilic inflammation. Clin Exp Allergy. 2010; 40:85-93. [PubMed: 19895589]

32. Barreto M, Villa MP, Olita C, Martella S, Ciabattoni G, Montuschi P. 8-Isoprostane in exhaled breath condensate and exercise-induced bronchoconstriction in asthmatic children and adolescents. Chest. 2009; 135:66-73. [PubMed: 18753466] 
33. Bodini A, Peroni D, Vicentini L, Loiacono A, Baraldi E, Ghiro L, Corradi M, Alinovi R, Boner AL, Piacentini GL. Exhaled breath condensate eicosanoids and sputum eosinophils in asthmatic children: a pilot study. Pediatr Allergy Immunol. 2004; 15:26-31. [PubMed: 14998379]

34. Bochner BS, Busse WW. Allergy and asthma. The Journal of allergy and clinical immunology. 2005; 115:953-959. [PubMed: 15867851]

35. Kinsella BT, O'Mahony DJ, Fitzgerald GA. The human thromboxane A2 receptor alpha isoform (TP alpha) functionally couples to the G proteins Gq and G11 in vivo and is activated by the isoprostane 8-epi prostaglandin F2 alpha. The Journal of pharmacology and experimental therapeutics. 1997; 281:957-964. [PubMed: 9152406]

36. Shiraki A, Kume H, Oguma T, Makino Y, Ito S, Shimokata K, Honjo H, Kamiya K. Role of Ca2+ mobilization and $\mathrm{Ca} 2+$ sensitization in 8-iso-PGF 2 alpha-induced contraction in airway smooth muscle. Clin Exp Allergy. 2009; 39:236-245. [PubMed: 19134015]

37. Fukunaga M, Yura T, Grygorczyk R, Badr KF. Evidence for the distinct nature of F2-isoprostane receptors from those of thromboxane A2. The American journal of physiology. 1997; 272:F477F483. [PubMed: 9140048]

38. Janssen LJ. Isoprostanes and lung vascular pathology. Am J Respir Cell Mol Biol. 2008; 39:383389. [PubMed: 18441279]

39. Breyer RM, Bagdassarian CK, Myers SA, Breyer MD. Prostanoid receptors: subtypes and signaling. Annu Rev Pharmacol Toxicol. 2001; 41:661-690. [PubMed: 11264472]

40. Cracowski JL, Durand T. Cardiovascular pharmacology and physiology of the isoprostanes. Fundam Clin Pharmacol. 2006; 20:417-427. [PubMed: 16968413]

41. Kawikova I, Barnes PJ, Takahashi T, Tadjkarimi S, Yacoub MH, Belvisi MG. 8-Epi-PGF2 alpha, a novel noncyclooxygenase-derived prostaglandin, constricts airways in vitro. American journal of respiratory and critical care medicine. 1996; 153:590-596. [PubMed: 8564103]

42. Janssen LJ, Premji M, Netherton S, Catalli A, Cox G, Keshavjee S, Crankshaw DJ. Excitatory and inhibitory actions of isoprostanes in human and canine airway smooth muscle. The Journal of pharmacology and experimental therapeutics. 2000; 295:506-511. [PubMed: 11046082]

43. Liu C, Tazzeo T, Janssen LJ. Isoprostane-induced airway hyperresponsiveness is dependent on internal Ca2+ handling and Rho/ROCK signaling. American journal of physiology. 2006; 291:L1177-L1184. [PubMed: 16815891]

44. Fortner CN, Breyer RM, Paul RJ. EP2 receptors mediate airway relaxation to substance P, ATP, and PGE2. American journal of physiology. 2001; 281:L469-L474. [PubMed: 11435222]

45. Catalli A, Zhang D, Janssen LJ. Receptors and signaling pathway underlying relaxations to isoprostanes in canine and porcine airway smooth muscle. American journal of physiology. 2002; 283:L1151-L1159. [PubMed: 12376370]

46. Catalli A, Janssen LJ. Augmentation of bovine airway smooth muscle responsiveness to carbachol, $\mathrm{KCl}$, and histamine by the isoprostane 8-iso-PGE2. American journal of physiology. 2004; 287:L1035-L1041. [PubMed: 15257985]

47. Spicuzza L, Barnes PJ, Di Maria GU, Belvisi MG. Effect of 8-iso-prostaglandin F(2 alpha) on acetylcholine release from parasympathetic nerves in guinea pig airways. Eur J Pharmacol. 2001; 416:231-234. [PubMed: 11290373]

48. Clarke DL, Giembycz MA, Patel HJ, Belvisi MG. E-ring 8-isoprostanes inhibit ACh release from parasympathetic nerves innervating guinea-pig trachea through agonism of prostanoid receptors of the EP3-subtype. Br J Pharmacol. 2004; 141:600-609. [PubMed: 14744812]

49. Paredes C, Tazzeo T, Janssen LJ. E-ring isoprostane augments cholinergic neurotransmission in bovine trachealis via FP prostanoid receptors. Am J Respir Cell Mol Biol. 2007; 37:739-747. [PubMed: 17630320]

50. Clarke DL, Belvisi MG, Hardaker E, Newton R, Giembycz MA. E-ring 8-isoprostanes are agonists at EP2- and EP4-prostanoid receptors on human airway smooth muscle cells and regulate the release of colony-stimulating factors by activating cAMP-dependent protein kinase. Mol Pharmacol. 2005; 67:383-393. [PubMed: 15528403]

51. Clarke D, Damera G, Sukkar MB, Tliba O. Transcriptional regulation of cytokine function in airway smooth muscle cells. Pulm Pharmacol Ther. 2009; 22:436-445. [PubMed: 19393330] 
52. Hogg JC, van Eeden S. Pulmonary and systemic response to atmospheric pollution. Respirology (Carlton, Vic. 2009; 14:336-346.

53. Beck-Speier I, Dayal N, Karg E, Maier KL, Schumann G, Schulz H, Semmler M, Takenaka S, Stettmaier K, Bors W, Ghio A, Samet JM, Heyder J. Oxidative stress and lipid mediators induced in alveolar macrophages by ultrafine particles. Free radical biology \& medicine. 2005; 38:1080 1092. [PubMed: 15780766]

54. Leitinger N, Huber J, Rizza C, Mechtcheriakova D, Bochkov V, Koshelnick Y, Berliner JA, Binder BR. The isoprostane 8-iso-PGF(2alpha) stimulates endothelial cells to bind monocytes: differences from thromboxane-mediated endothelial activation. FASEB J. 2001; 15:1254-1256. [PubMed: 11344105]

55. Scholz H, Yndestad A, Damas JK, Waehre T, Tonstad S, Aukrust P, Halvorsen B. 8-isoprostane increases expression of interleukin- 8 in human macrophages through activation of mitogenactivated protein kinases. Cardiovasc Res. 2003; 59:945-954. [PubMed: 14553834]

56. Zahler S, Becker BF. Indirect enhancement of neutrophil activity and adhesion to cultured human umbilical vein endothelial cells by isoprostanes (iPF2alpha-III and iPE2-III). Prostaglandins Other Lipid Mediat. 1999; 57:319-331. [PubMed: 10480486]

57. Hart CM, Karman RJ, Blackburn TL, Gupta MP, Garcia JG, Mohler ER 3rd. Role of 8-epi PGF2alpha, 8-isoprostane, in $\mathrm{H} 2 \mathrm{O} 2$-induced derangements of pulmonary artery endothelial cell barrier function. Prostaglandins Leukot Essent Fatty Acids. 1998; 58:9-16. [PubMed: 9482161]

58. Rossi A, Kapahi P, Natoli G, Takahashi T, Chen Y, Karin M, Santoro MG. Anti-inflammatory cyclopentenone prostaglandins are direct inhibitors of IkappaB kinase. Nature. 2000; 403:103108. [PubMed: 10638762]

59. Sawyer K, Mundandhara S, Ghio AJ, Madden MC. The effects of ambient particulate matter on human alveolar macrophage oxidative and inflammatory responses. Journal of toxicology and environmental health. 2010; 73:41-57. [PubMed: 19953419]

60. Cowley EA. Isoprostane-mediated secretion from human airway epithelial cells. Mol Pharmacol. 2003; 64:298-307. [PubMed: 12869634]

61. Joy AP, Cowley EA. 8-iso-PGE2 stimulates anion efflux from airway epithelial cells via the EP4 prostanoid receptor. Am J Respir Cell Mol Biol. 2008; 38:143-152. [PubMed: 17690331]

62. Seto V, Hirota C, Hirota S, Janssen LJ. E-Ring Isoprostanes Stimulate a Cl Conductance in Airway Epithelium via Prostaglandin E2-Selective Prostanoid Receptors. Am J Respir Cell Mol Biol. 2008; 38:88-94. [PubMed: 17673688]

63. Montuschi P, Corradi M, Ciabattoni G, Nightingale J, Kharitonov SA, Barnes PJ. Increased 8isoprostane, a marker of oxidative stress, in exhaled condensate of asthma patients. American journal of respiratory and critical care medicine. 1999; 160:216-220. [PubMed: 10390403]

64. Wood LG, Fitzgerald DA, Gibson PG, Cooper DM, Garg ML. Lipid peroxidation as determined by plasma isoprostanes is related to disease severity in mild asthma. Lipids. 2000; 35:967-974. [PubMed: 11026617]

65. Baraldi E, Ghiro L, Piovan V, Carraro S, Ciabattoni G, Barnes PJ, Montuschi P. Increased exhaled 8-isoprostane in childhood asthma. Chest. 2003; 124:25-31. [PubMed: 12853498]

66. Zanconato S, Carraro S, Corradi M, Alinovi R, Pasquale MF, Piacentini G, Zacchello F, Baraldi E. Leukotrienes and 8-isoprostane in exhaled breath condensate of children with stable and unstable asthma. The Journal of allergy and clinical immunology. 2004; 113:257-263. [PubMed: 14767439]

67. Mondino C, Ciabattoni G, Koch P, Pistelli R, Trove A, Barnes PJ, Montuschi P. Effects of inhaled corticosteroids on exhaled leukotrienes and prostanoids in asthmatic children. The Journal of allergy and clinical immunology. 2004; 114:761-767. [PubMed: 15480313] 


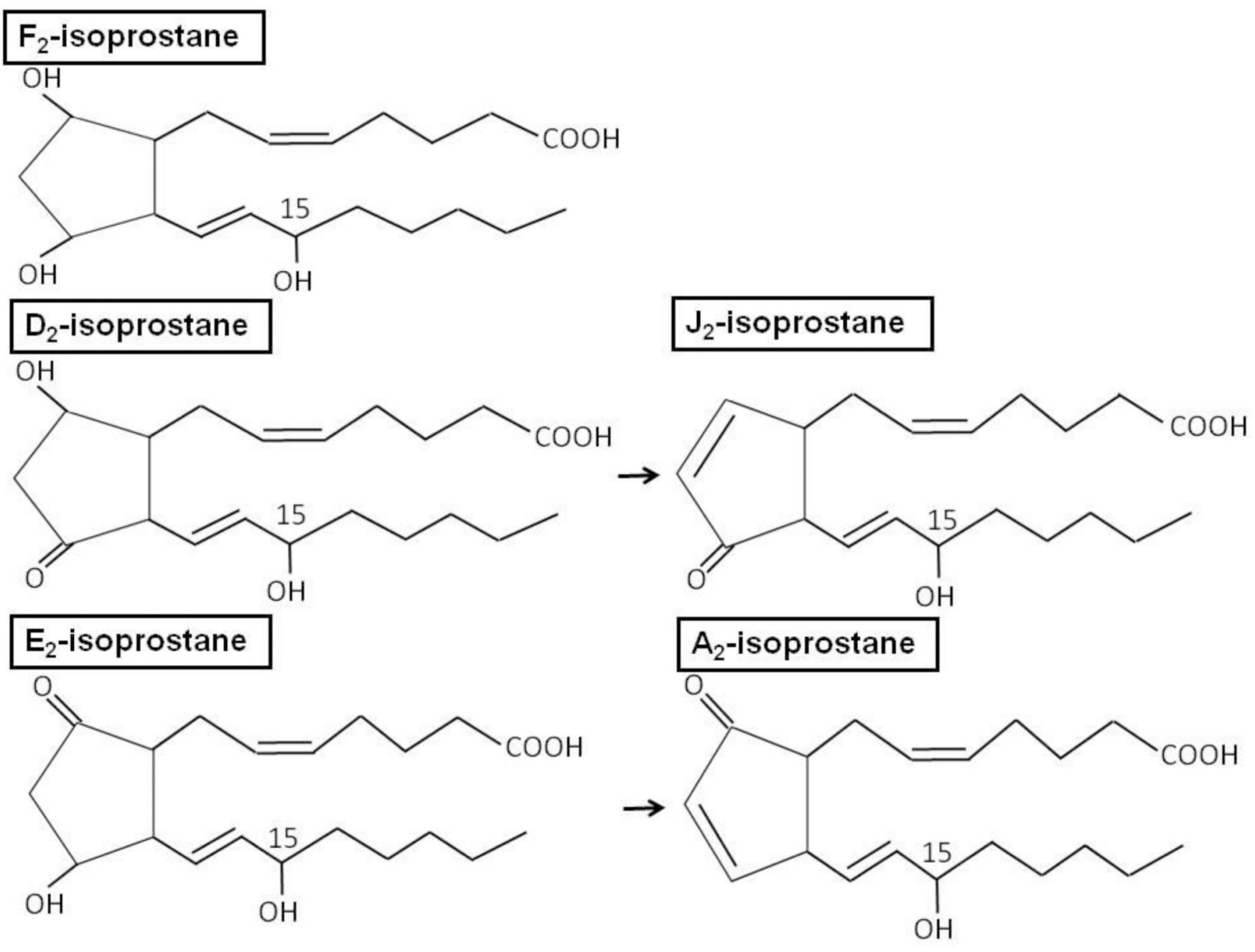

Figure 1.

Isoprostane structure. Four major regioisomers of isoprostanes are formed defined by the location of the hydroxyl group on the alkyl chains. The 15- and 5-hydroxyl forms are the most abundant compared to the 8- and 12- series. The 15- regioisomer is depicted here. $\mathrm{F}_{2}-$ and $\mathrm{D}_{2}$ - and $\mathrm{E}_{2}$ are all formed from an endoperoxide intermediate derived from peroxidation of arachidonic acid. The $\mathrm{D}_{2}$ and $\mathrm{E}_{2}$-isoprostanes have a ketone and hydroxyl group on the cyclopentane ring that are reduced to form the $\mathrm{J}_{2}$ and $\mathrm{A}_{2}$-isoprostanes respectively with cyclopentenone rings. 
Table 1

$\mathrm{F}_{2}$-Isoprostane Levels in Asthma

\begin{tabular}{|c|c|c|c|}
\hline Study Design & $F_{2}$-isoP Levels & Reactive oxygen species & Ref \\
\hline Adults: & & & {$[63]$} \\
\hline 10 Healthy $*$ & $15.8 \pm 1.6(\mathrm{pg} / \mathrm{ml})^{a}$ & $\mathrm{eNO}(\mathrm{ppb})^{b}: 6.5 \pm 0.6$ & \\
\hline 12 Mild Asthma* & $33.7 \pm 2.8$ & $22.6 \pm 2.9$ & \\
\hline 17 Moderate ${ }^{*}$ & $38.3 \pm 3.7$ & $11.9 \pm 1.3$ & \\
\hline 15 Severe $^{*}$ & $49.1 \pm 5.0$ & $10 \pm 1.8$ & \\
\hline$\underline{\text { Adults: }}$ & & & {$[29]$} \\
\hline 9 Mild Atopic Asthma & & & \\
\hline Segmental allergen challenge & & & \\
\hline BAL-pre & $0.9 \pm 0.2(\mathrm{pg} / \mathrm{ml})^{c}, d$ & & \\
\hline $24 \mathrm{~h}$ after & $11.4 \pm 3$ & & \\
\hline Urine-pre & $1.5 \pm 0.2(\mathrm{ng} / \mathrm{mg}$ creat $)$ & & \\
\hline $2-8 \mathrm{~h}$ after & $2.6 \pm 0.3$ & & \\
\hline Adults: & & & {$[25]$} \\
\hline 38 Healthy & $23.9(17.2-48.9)^{g}, e$ & $\mathrm{eNO}(\mathrm{ppb})^{b}: 15.9(12-21)$ & \\
\hline 57 Asthma $^{\#}$ & $46.9(28.6-71.5)$ & $41.6(16.4-83.1)$ & \\
\hline Children: & & & {$[64]$} \\
\hline 15 Healthy $^{+}$ & $139(109-174)(\mathrm{pg} / \mathrm{ml})^{e}$ & & \\
\hline 15 Asthma $^{+}$ & $213(122-455)$ & & \\
\hline Children: & & & {$[65]$} \\
\hline 12 Healthy ${ }^{*}$ & $34.2 \pm 4.5(\mathrm{pg} / \mathrm{ml})^{f}$ & $\mathrm{PGE}_{2}(\mathrm{pg} / \mathrm{ml})^{f}: 46.8 \pm 5.3$ & \\
\hline 12 Asthma/non-steroid* & $56.4 \pm 7.7$ & $44.6 \pm 5.0$ & \\
\hline 30 Asthma/steroid-treated ${ }^{*}$ & $47.2 \pm 2.3$ & $51.5 \pm 4.0$ & \\
\hline Children: & & $\mathrm{LTC}_{4} / \mathrm{D}_{4} / \mathrm{E}_{4}^{e}$ & {$[27]$} \\
\hline 10 Healthy ${ }^{*}$ & $2.6(2.1-3.0)(\mathrm{pg} / \mathrm{ml})^{a, e}$ & $4.3(2-5.7)$ & \\
\hline 15 Asthma-Exacerbation * & $12.0(9.4-29.5)$ & $12.7(5.4-15.6)$ & \\
\hline Post- prednisone ${ }^{*}$ & $8.4(5.4-11.6)$ & $5.2(3.9-8.8)$ & \\
\hline Children: & & $\mathrm{LTC}_{4} / \mathrm{D}_{4} / \mathrm{E}_{4}{ }^{a}$ & {$[33]$} \\
\hline 12 Asthma, + HDM ${ }^{*}$ & $17.47 \pm 3.18(\mathrm{pg} / \mathrm{ml})^{a}$ & $14.24 \pm 4.53$ & \\
\hline HDM avoidance, 3 months $*$. & $7.36 \pm 3.26$ & $4.65 \pm 0.68$ & \\
\hline Children: & & $\mathrm{LTC}_{4} / \mathrm{D}_{4} / \mathrm{E}_{4}^{e}$ & {$[66]$} \\
\hline 19 Healthy $*$ & $3.5(2.6-7.9)(\mathrm{pg} / \mathrm{ml})^{e}$ & $4.3(2-8.3)$ & \\
\hline
\end{tabular}




\begin{tabular}{|c|c|c|c|}
\hline Study Design & $F_{2}$-isoP Levels & Reactive oxygen species & Ref. \\
\hline 14 Asthma/ non-steroid ${ }^{*}$ & $16.2(11.7-19.1)$ & $10.8(9.3-13.1)$ & \\
\hline 13 ICS-treated Asthma* & $18.1(14.8-20.5)$ & $12.7(9.9-15.1)$ & \\
\hline 9 Unstable Asthma ${ }^{*}$ & $29.7(4.8-35.1)$ & $106.0(4.2-218)$ & \\
\hline Children: & & $\mathrm{LTE}_{4} a, e$ & [67] \\
\hline 20 Healthy* & $15.5(14.1-17.5)^{f, e}$ & $12.5(11.6-14.7)$ & \\
\hline 20 Atopic/non-Asthma ${ }^{*}$ & $15.8(13.9-20.1)$ & $15.9(12-17.5)$ & \\
\hline 30 Atopic/Asthma ${ }^{*}$ & $29.8(26-34.3)$ & $28.2(24.9-35.7)$ & \\
\hline 25 Atopic/Asthma/ICS $*$ & $33(28.5-35.8)$ & $29(25-36.6)$ & \\
\hline Children: & & & [28] \\
\hline 11 Healthy* & $3.8 \pm 0.6(\mathrm{pg} / \mathrm{ml})^{a}$ & & \\
\hline 13 Asthma/ non-steroid * & $9.3 \pm 1.7$ & & \\
\hline 12 ICS-treated Asthma * & $6.7 \pm 0.7$ & & \\
\hline Children: & & & [32] \\
\hline Asthma & Pre-exercise $(\mathrm{pg} / \mathrm{ml})^{f}$ & & \\
\hline 34 non-EIB $*$ & $32.3(27.6-37)$ & & \\
\hline $12 \mathrm{EIB}^{*}$ & $44.9(38.3-51.5)$ & & \\
\hline
\end{tabular}

${ }^{a}$ EIA (Cayman Chemical);

${ }^{b}$ Chemiluminescence analyzer;

${ }^{c}$ Gas chromatography/negative-ion chemical ionization mass spectrometry (GC/NICI/MS);

${ }^{d}$ No immediate release of $\mathrm{F}_{2}$-isoP into BAL after allergen challenge;

${ }^{e}$ median and quartile range;

$f_{\text {RIA; }}$

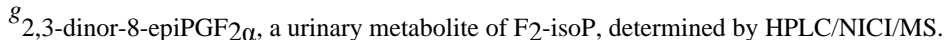

Source of analysis:

EBC,

+ Plasma,

${ }^{\#}$ Urine. 